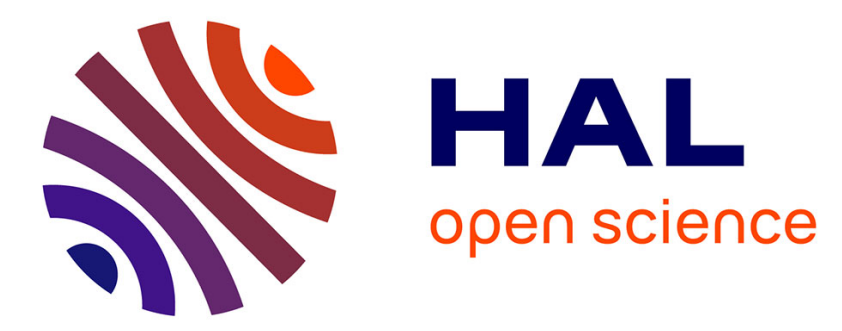

\title{
Spectra and structures of the Pdm-CO complexes: An infrared matrix isolation and density functional study
}

Mohammad Esmaïl Alikhani, S.M.O. Souvi, Mohamad Ibrahim, B. Tremblay

\section{To cite this version:}

Mohammad Esmaïl Alikhani, S.M.O. Souvi, Mohamad Ibrahim, B. Tremblay. Spectra and structures of the Pdm-CO complexes: An infrared matrix isolation and density functional study. Journal of Molecular Spectroscopy, 2019, 361, pp.8-15. 10.1016/j.jms.2019.05.001 . hal-02179332

\section{HAL Id: hal-02179332 \\ https://hal.sorbonne-universite.fr/hal-02179332}

Submitted on 10 Jul 2019

HAL is a multi-disciplinary open access archive for the deposit and dissemination of scientific research documents, whether they are published or not. The documents may come from teaching and research institutions in France or abroad, or from public or private research centers.
L'archive ouverte pluridisciplinaire HAL, est destinée au dépôt et à la diffusion de documents scientifiques de niveau recherche, publiés ou non, émanant des établissements d'enseignement et de recherche français ou étrangers, des laboratoires publics ou privés. 


\title{
Spectra and structures of the $\mathrm{Pd}_{\mathrm{m}}-\mathrm{CO}$ complexes:
}

\section{An Infrared Matrix Isolation and Density Functional study}

M.E. Alikhani ${ }^{1, *}$, S.M.O. Souvi ${ }^{2}$, M. Ibrahim ${ }^{1}$ and B. Tremblay ${ }^{1, *}$

1 - Sorbonne Université, CNRS, UMR 8233, MONARIS, Case courrier 49, 4 place Jussieu, F-75005, Paris, France

2 - Institut de Radioprotection et de Sûreté Nucléaire (IRSN), PSN-RES/SAG/LETR, Cadarache, St Paul Lez Durance 13115, France

\begin{abstract}
The $\mathrm{Pd}+\mathrm{CO}$ reaction has been reinvestigated using deposition of ground state reagents in solid argon and neon and the formation of $\mathrm{Pd}_{\mathrm{m}}-\mathrm{CO}(\mathrm{m}=2-4)$ and $\mathrm{Pd}_{2}-(\mathrm{CO})_{2}$ molecules is evidenced by many absorption in the range of 2015-1700 $\mathrm{cm}^{-1}$. These bands are also accompanied by other signals in far-infrared. In argon, selective irradiation in visible leads to conversion between two $\mathrm{Pd}_{2}-\mathrm{CO}$ isomers distinguished by the stretching frequency of the diatomic $\mathrm{CO}$ : bridged T-shaped $\left(v_{\mathrm{CO}}=1856 \mathrm{~cm}^{-1}\right)$ and side on $\left(v_{\mathrm{CO}}=2015 \mathrm{~cm}^{-1}\right)$. The experimental data, with the help of isotopic effects, are fully supported by theoretical calculations with density functional theory. The nature of chemical bonding has been also discussed within the topological approach. It has been shown that the $\mathrm{CO}$ complex adapts his valence basins to the geometrical symmetry of $\mathrm{Pd}_{\mathrm{m}}-\mathrm{CO}$ when interacting with $\mathrm{Pd}_{\mathrm{m}}$ clusters.
\end{abstract}

*Authors to whom correspondence should be addressed.

E-mail:esmail.alikhani@sorbonne-universite.fr, Tel :33144273072; benoit.tremblay@sorbonne-universite.fr, Tel : 33144273835

Keywords: Palladium, cluster, carbon monoxide, DFT, infrared, matrix isolation 


\section{Introduction}

The important role played by the $\mathrm{CO}$ complex in transition metal complexes has stimulated both theoretical and experimental studies on model compounds. For this reason, the matrix isolation technique has been applied early to the characterization of simple, unsaturated binary $\mathrm{M}(\mathrm{CO})_{\mathrm{n}}(\mathrm{n}=1$ to 4,5 , or 6$)$ transition metal carbonyls [1]. When annealing the sample to promote aggregation or using high metal/rare gas ratio, polynuclear metal carbonyls were formed, but their clear identification proved to be difficult since a large number of species appears in the spectrum. Also, the data were restricted to frequencies of the strongly absorbing $\mathrm{CO}$ carbonyl stretching

Recently, many works have been reported on the $\mathrm{M}_{2}+\mathrm{CO}$ reaction by trapping evaporated $\mathrm{M}$ atoms $(\mathrm{Au}$, $\mathrm{Sc}, \mathrm{Pb}, \mathrm{Ti}, \mathrm{La}, \mathrm{Y}, \mathrm{Ag}, \mathrm{Gd}$, and $\mathrm{Cu}$ ) and carbon monoxide in solid argon [2-13]. Different structures have been obtained for the $\mathrm{M}_{2} \mathrm{CO}$ complexes from one dimer metal to another: terminal $\mathrm{CO}$, asymmetric $\mathrm{M}_{2}\left[\eta^{2}-(\mu-\mathrm{C}, \mathrm{O})\right]$, and cyclic $\mathrm{M}_{2}(\mu-\mathrm{C})(\mu-\mathrm{O})$. The last two structures were formed on annealing or by ultraviolet-visible photoinduced rearrangement to the CO-dissociated molecule. In all these studies, DFT (density functional theory) calculations were also performed to describe ground state geometries, bonding properties and vibrational analyses. Recently, two systematic theoretical studies of the interaction of carbon monoxide with transition metal dimers (with $3 \mathrm{~d}$ metal [14] and 4d metal [15]) pointed out that the ground state configurations are very different from one metal to another (side-on-bonded, bridging, or linear).

Concerning the $\mathrm{Pd}_{\mathrm{m}}-\mathrm{CO}$ complexes, with $\mathrm{m}>2$, the experimental results are rather scarce. The $\mathrm{CO}$ adsorption over metal particles or surface shows a stretching frequency in the range $1950-2140 \mathrm{~cm}^{-1}$ when $\mathrm{CO}$ is

absorbed on one metal atom, $1800-2000 \mathrm{~cm}^{-1}$ for $\mathrm{CO}$ bridging two metal sites and $1700-1900 \mathrm{~cm}^{-1}$ for $\mathrm{CO}_{\mathrm{on}}$ threefold-hollow sites [16]. In an experimental work dedicated to the reaction of laser-ablated palladium atoms 
with carbon monoxide in solid neon, a band at $1878.8 \mathrm{~cm}^{-1}$ was tentatively assigned at $\mathrm{Pd}_{2}-\mathrm{CO}$ on the basis of annealing behaviours [17].

The $\mathrm{Pd}_{2}-\mathrm{CO}$ complex has been considered in several theoretical studies [15, 18-33]. All molecular ab initio and DFT studies are unanimous on the fact that the ground state structure of this complex is a singlet with $\mathrm{C}_{2 \mathrm{v}}$ symmetry $\left(\mathrm{X}^{1} \mathrm{~A}_{1}\right.$ state). Using a high level approach MRSDCI-Q [22], Dai and Balasubraminan reported several bridged and linear states for the neutral $\mathrm{Pd}_{2}-\mathrm{CO}$ complex. Compared to the ground state of $\mathrm{Pd}_{2}-\mathrm{CO}($ with a binding energy of $-75.5 \mathrm{kcal} / \mathrm{mol})$, the three lowest excited states $\left({ }^{1} \Sigma^{+},{ }^{3} \Delta\right.$, and $\left.{ }^{3} \mathrm{~B}_{2}\right)$ are found to be higher than the ground state by $40.8,44.5$, and $58.8 \mathrm{kcal} / \mathrm{mol}$, respectively. In another theoretical work [31], a side-on structure $\left(\mathrm{C}_{\mathrm{s}}\right.$ symmetry) has been also suggested as a possible a-top adsorption site for $\mathrm{CO}$ in singlet state (23 $\mathrm{kcal} / \mathrm{mol}$ higher than the $\mathrm{X}^{1} \mathrm{~A}_{1}$ state).

Many theoretical studies have been carried out on the $\mathrm{Pd}_{3}-\mathrm{CO}[19,28-34]^{19,28-34}$ and $\mathrm{Pd}_{4}-\mathrm{CO}[18,19,29-$ 33,35-40] complexes to simulate the CO chemisorption on palladium cluster on surface. Almost all the studies find a fundamental state with a hollow $\mathrm{CO}$ with a $\mathrm{C}_{3 \mathrm{~V}}$ symmetry [19,28-33]. In many studies, the C-O harmonic stretching frequencies are given and in a few studies, the low frequency mode $\mathrm{Pd}-\mathrm{C}$ is also given.

We report here data concerning fundamental vibrations for several isotopic $\mathrm{CO}$ species $\left({ }^{12} \mathrm{C}^{16} \mathrm{O},{ }^{13} \mathrm{C}^{16} \mathrm{O}\right.$, and $\left.{ }^{12} \mathrm{C}^{18} \mathrm{O}\right)$ of $\mathrm{Pd}_{2}-\mathrm{CO}, \mathrm{Pd}_{3}-\mathrm{CO}, \mathrm{Pd}_{4}-\mathrm{CO}$, and $\mathrm{Pd}_{2}-(\mathrm{CO})_{2}$ isolated in solid argon and neon. DFT calculations of the geometrical and electronic properties of $\mathrm{Pd}_{\mathrm{m}}-\mathrm{CO}(\mathrm{m}=2-4)$ complexes are also presented on the singlet and triplet states. For all the complexes, calculated vibrational frequencies are compared to the experimental values.

\section{Experimental and computational details}

The experimental set-up for matrix isolation Fourier transform infrared (FTIR) spectroscopic investigation has been described in detail previously [41]. Briefly, the $\mathrm{Pd}_{\mathrm{m}}(\mathrm{CO})_{\mathrm{n}}$ (or $\left.\mathrm{m}: \mathrm{n}\right)$ complexes were prepared by co- 
condensation of palladium atomic vapor and $\mathrm{CO}$-rare gas mixtures onto one a flat, highly polished, Rh-plated copper mirror maintained at temperatures between 3 and $6 \mathrm{~K}$ (neon) or 12 and $21 \mathrm{~K}$ (argon) using a closed-cycle cryogenerator (model PT405, Cryomech, Syracuse NY, USA). A tungsten filament, mounted in a furnace assembly and wetted with palladium (Aldrich, $99.9 \%$ ) was heated at about $1400{ }^{\circ} \mathrm{C}$ to generate $\mathrm{Pd}$ vapour. The metal deposition rate, controlled by a quartz microbalance, was of the order of 1 microgram/min. High-purity argon (Air Liquide, 99.998 \%), neon (Air Liquide, $99.9995 \%$ ), and carbon monoxide (Matheson; $99.5 \%$ ), ${ }^{13} \mathrm{CO}\left(\mathrm{CEA}\right.$, Saclay, France; $99 \%{ }^{13} \mathrm{C}$, including $\left.8 \%{ }^{13} \mathrm{C}^{18} \mathrm{O}\right),{ }^{12} \mathrm{C}^{18} \mathrm{O}\left(\mathrm{MSD} ; 98 \%{ }^{18} \mathrm{O}\right.$ ) were used to prepare the CO-rare gas mixtures after removing condensable impurities with a liquid nitrogen trap.

The carbon monoxide/rare gas molar ratio was varied between $10^{-3}$ and $10^{-5}$ in argon in order to minimize the formation of $1: \mathrm{n}, \mathrm{n}>1$, aggregates and typically around $3 \times 10^{-4}$ in neon. The deposition rate of this mixture was typically $1 \mathrm{~cm}^{3} / \mathrm{min}$, which correspond to a CO/Pd molar ratio between 3 and 0.03 in argon, and to 0.1 in neon. In these conditions, the formation of m:1 aggregates are favorized. In general, after 90 min of deposition, infrared spectra of the resulting sample were recorded, at $3 \mathrm{~K}(\mathrm{Ne})$ and $12 \mathrm{~K}(\mathrm{Ar})$, in the transmission-reflection mode between 5000 and $75 \mathrm{~cm}^{-1}$ using a Bruker $120 \mathrm{FTIR}$ spectrometer and suitable combinations of $\mathrm{Ge} / \mathrm{KBr}$ or $\mathrm{Si} /$ Mylar composite beam splitters with either liquid $\mathrm{N}_{2}$-cooled InSb or narrow band $\mathrm{HgCdTe}$ photoconductor or a liquid He-cooled Si-B bolometer with a $4 \mathrm{~K}$-cooled $660 \mathrm{~cm}^{-1}$ lowpass filter. The resolution was varied between 0.1 and $0.5 \mathrm{~cm}^{-1}$. Also, absorption spectra in the mid- and far infrared were collected on the same samples through either CsI or polyethylene windows mounted on a rotatable flange separating the interferometer vacuum $\left(10^{-3} \mathrm{mbar}\right)$ from that of the cryostatic cell $\left(10^{-7} \mathrm{mbar}\right)$. The spectra were subsequently subjected to baseline correction to compensate for infrared light scattering and interference patterns. The sample was next either annealed in order to increase the abundance of aggregates (if necessary) or irradiated at various wavelength using a $200 \mathrm{~W} \mathrm{Hg-Xe} \mathrm{high-pressure} \mathrm{arc} \mathrm{lamp} \mathrm{and} \mathrm{interference} \mathrm{filters} \mathrm{transmitting} \mathrm{in} \mathrm{a} \mathrm{wavelength}$ range of $\pm 5 \mathrm{~nm}$ around the nominal value. 
Theoretical calculations have been performed with the GAUSSIAN 09 quantum chemical package [42] using DFT approach with unrestricted wave function. The TPSS meta-GGA functional with the extended 6$311+\mathrm{G}(2 \mathrm{df})$ basis set for $\mathrm{C}$ and $\mathrm{O}$ and SDD pseudopotential and corresponding basis set for Pd atom have been used. The nature of chemical bonds between metal-metal and metal-ligand has been investigated using the QTAIM topological approach [43] with the AIMALL software [44].

\section{Experimental part}

\subsection{Concentration, annealing and isotopic effects}

$\mathrm{Pd}$ vapor was condensed with relatively dilute mixtures of $\mathrm{CO}$ in argon (1/1000) at $21 \mathrm{~K}$ to favor formation of monocarbonyls $\mathrm{Pd}_{\mathrm{m}}-\mathrm{CO}$. The infrared spectrum of the products obtained after deposition of palladium atoms, with a $\mathrm{Pd} / \mathrm{Ar}$ ratio of $0.4 / 1000$, codeposited with $1 / 1000 \mathrm{CO}$ in argon at $21 \mathrm{~K}$ is shown in Fig. 1. After a 90 min sample deposition, several strong absorptions were observed in the CO stretching domain. The previously assigned $\mathrm{Pd}-(\mathrm{CO})_{4}, \mathrm{Pd}-(\mathrm{CO})_{3}, \mathrm{Pd}-(\mathrm{CO})_{2}$, and $\mathrm{Pd}-\mathrm{CO}$ complexes [45] appear at 2070.5, 2056.4,

2051.6, 2050.4, and $2044.0 \mathrm{~cm}^{-1}$ (the last two bands correspond to the Pd-CO complex in two trapping sites) [46]. In fact, some $\mathrm{Pd}_{\mathrm{m}}-(\mathrm{CO})_{\mathrm{n}}$ complexes, noted $\mathrm{m}: \mathrm{n}$, present trapping site effects in argon and neon matrices. In what follows, we shall focus on the frequencies measured for the main sites, as the signals are stronger and sharper, and therefore allowing a more precise discussion.

Outside the absorption domain of the of $\mathrm{Pd}-(\mathrm{CO})_{\mathrm{n}}$ complexes, two strong bands are measured at 2014.9 and $1856.5 \mathrm{~cm}^{-1}$, and four weaker ones at 2064.5, 1880.2, 1729.4 and $1693.5 \mathrm{~cm}^{-1}$ (Fig. 1). The two strong bands keep a relatively constant intensity ratio about $1 / 0.7$ after deposition, and they have the same CO concentration dependence as the one at $2044.0 \mathrm{~cm}^{-1}$ assigned to the $1: 1$ species. The four others have a relatively constant intensity ratio of 1/0.1 after deposition, and they can be observed only with a high Pd concentration. 
More precisely, experiments performed at a constant concentration in $\mathrm{CO}$ (of the order of $1000 \mathrm{ppm}$ ) show that the intensity of the bands at 1729.4 and $1693.5 \mathrm{~cm}^{-1}$ increases faster than that of the strong bands at 2014.9 and $1856.5 \mathrm{~cm}^{-1}$ when Pd concentration increases. As an example, when this concentration increases by a factor of 2, the intensity of the bands at 2014.9 and $1856.5 \mathrm{~cm}^{-1}$ is multiplied by 3 , that of the band at $1729.4 \mathrm{~cm}^{-1}$ by 6 and that of the band at $1693.5 \mathrm{~cm}^{-1}$ by 10 , while that of $1: 1$ increases by $50 \%$. This suggests a stoichiometry in Pd greater for these species responsible for the bands at 1729.4 and $1693.5 \mathrm{~cm}^{-1}, \mathrm{n}=3$ and $\mathrm{n}=4$, respectively, as discussed later. For the two weak bands at 2064.5 and $1880.2, \mathrm{~cm}^{-1}$, they always correlate and they have the same $\mathrm{CO}$ and $\mathrm{Pd}$ concentration dependence.

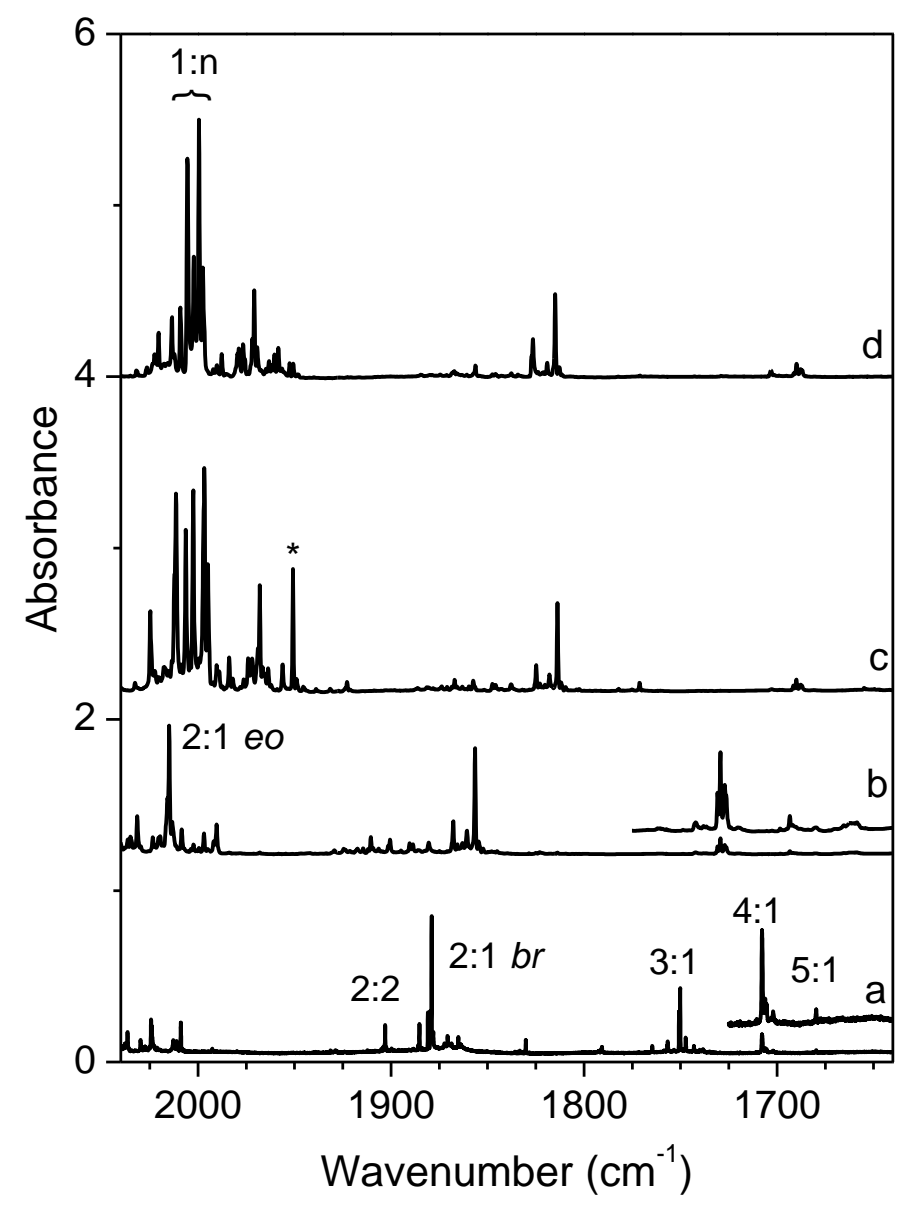

Fig. 1. Infrared spectra for $\mathrm{Pd} / \mathrm{CO} / \mathrm{Ar}$ or Ne mixtures in the $\mathrm{CO}$ stretching region for various isotopic precursors. (a) natural $\mathrm{CO}$ with a $\mathrm{Pd} / \mathrm{CO} / \mathrm{Ne}$ molar ratio of $0.3 / 0.2 / 1000$, and with a $\mathrm{Pd} / \mathrm{CO} / \mathrm{Ar}$ molar ratio of $0.4 / 1 / 1000$ 
for the next three spectra (b) natural $\mathrm{CO}(\mathrm{c}){ }^{13} \mathrm{C}^{16} \mathrm{O}$, and (d) $\mathrm{C}^{18} \mathrm{O}$. Since the ${ }^{13} \mathrm{CO}$ sample contains about $8 \%$ ${ }^{13} \mathrm{C}^{18} \mathrm{O}$ as isotopic impurity, the asterisk indicates the $\mathrm{Pd}^{13} \mathrm{C}^{18} \mathrm{O}$ species in (c). The upper part of (a) and (b) correspond to an absorbance scale divided by 5 .

All these observations are confirmed by annealing effects. With experimental conditions like in Fig. 1, a $\mathrm{Pd} / \mathrm{CO} / \mathrm{Ar}$ molar ratio of $0.4 / 1 / 1000$, at a same temperature deposition of $21 \mathrm{~K}$, performing controlled diffusion by annealing the sample up to $35 \mathrm{~K}$ to enhance the intensity of the bands. In this case, the intensity of the band at 2014.9 increases by $10 \%$, that of the band at $1856.5 \mathrm{~cm}^{-1}$ by $50 \%$, that of the band at $1729.4 \mathrm{~cm}^{-1}$ by 2 and that of the band at $1693.5 \mathrm{~cm}^{-1}$ by 4 , while that of $1: 1$ decreases by $5 \%$. Note also that the intensity of the band on unreacted $\mathrm{CO}$ decreases by around $10 \%$ and the bands of the $\mathrm{Pd}-(\mathrm{CO})_{\mathrm{n}}$ species, with $\mathrm{n}=2,3$ and 4 , growth lightly. The 2014.9 and $1856.5 \mathrm{~cm}^{-1}$ signals correspond to two isomers of $\mathrm{Pd}_{2}-\mathrm{CO}(2: 1)$, and as discussed later, referred to as end-on (eo) and bridged (br) in order of decreasing frequencies. The signal at 1729.4 is assigned to a $3: 1$ species, and the one at $1693.5 \mathrm{~cm}^{-1}$ to a $4: 1$ species. Finally, the two bands at 2064.5 and $1880.2, \mathrm{~cm}^{-1}$, favored by higher $\mathrm{CO}$ and $\mathrm{Pd}$ concentration, are assigned to a 2:2 species with two non-equivalent $\mathrm{CO}$ subcomplexes, a terminal one $\left(2064.5 \mathrm{~cm}^{-1}\right)$ and a bridge one $\left(1880.2 \mathrm{~cm}^{-1}\right)$. Also, the other small bands in the 2000-1700 $\mathrm{cm}^{-1}$ region have not a clear dependence in $\mathrm{CO}$ or Pd concentration, and we can considerate that they correspond to some m:n species.

Accompanying these absorptions in the $\mathrm{C}-\mathrm{O}$ stretching region, much weaker absorptions both in the far(Fig. 2) and near-infrared regions can be correlated to those reported above on the basis of concentration effects or/and upon matrix warm-up. Three of them at 483.9, 2498.4 and $4004.1 \mathrm{~cm}^{-1}$ (Table 1) behaved similarly to the strong band at $2014.9 \mathrm{~cm}^{-1}$. This shows that all these absorptions belong to the same species with an end-on CO. Three other absorptions at 386.5, 587.7 and $3688.1 \mathrm{~cm}^{-1}$ (Table 1) presented a similar intensity dependence with the band at $1856.5 \mathrm{~cm}^{-1}$, the other form of $2: 1$, with a bridging $\mathrm{CO}$. 
The experiments were repeated using isotopically labeled $\mathrm{CO}$, more specifically ${ }^{13} \mathrm{C}^{16} \mathrm{O}$ and ${ }^{12} \mathrm{C}^{18} \mathrm{O}$. The results of the isotopic study are presented in Figures 1-2 and Table 1. The broad absorption at $483.9 \mathrm{~cm}^{-1}$ appearing as a asymmetrical band under $0.5 \mathrm{~cm}^{-1}$ is resolved into a multiplet, with a FWHM of only $0.2 \mathrm{~cm}^{-1}$, with $0.1 \mathrm{~cm}^{-1}$ resolution (Fig. 2). The intensities of the components making up the multiplet are in the same proportions as the four more abundant natural isotopes of the palladium $(11,22,27$, and $27 \%$ abundance for the $104,105,106$, and 108 isotopes, respectively). Surprisingly this isotopic structure is close to that observed for the Pd-CO stretching mode of the $1: 1$ species [46] at $472 \mathrm{~cm}^{-1}$ (Fig. 2). This point will be discussed in the section devoted to the vibrational analysis. In the mixed ${ }^{12} \mathrm{C}^{16} \mathrm{O}+{ }^{13} \mathrm{C}^{16} \mathrm{O}$ experiment, no triplet with $1 / 2 / 1$ intensity distribution was produced for the $\mathrm{Pd}_{2}-(\mathrm{CO})_{2}$ complex, so two equivalent $\mathrm{CO}$ subcomplexes are not involved.

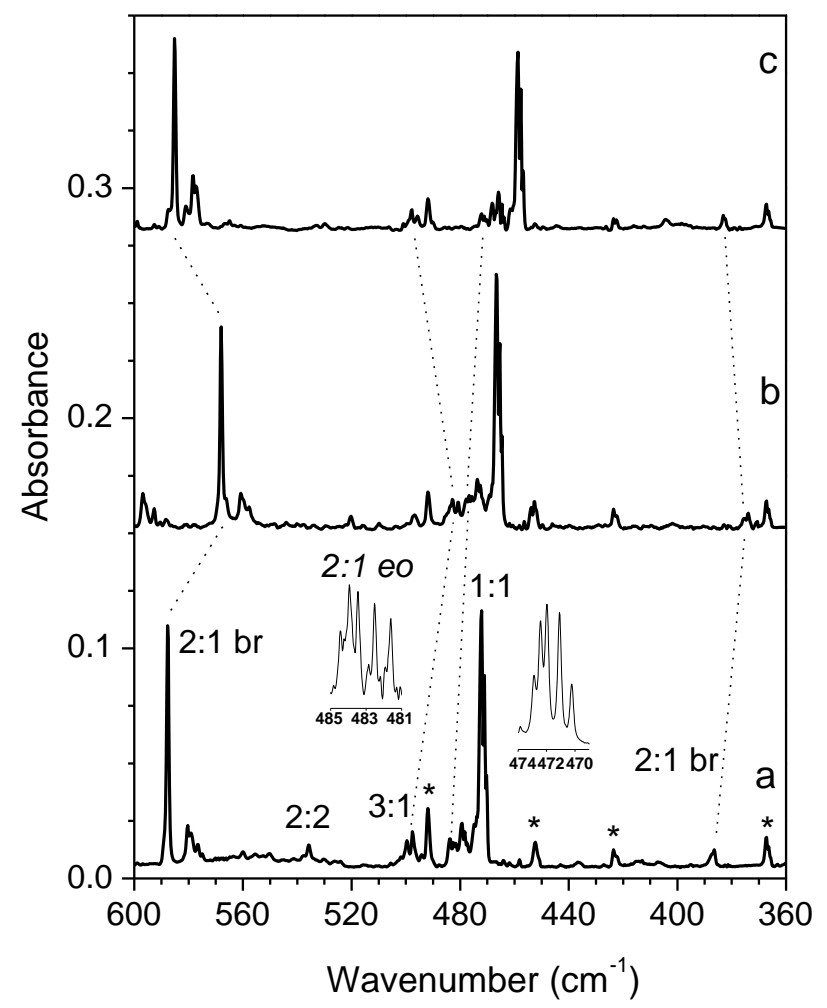


Fig. 2. Infrared spectra for $\mathrm{Pd} / \mathrm{CO} / \mathrm{Ar}$ mixtures in the $600-350 \mathrm{~cm}^{-1}$ region for various isotopic precursors at fixed $\mathrm{Pd} / \mathrm{CO} / \mathrm{Ar}$ molar ratios (3/1/1000). (a) natural $\mathrm{CO}$, (b) ${ }^{13} \mathrm{C}^{16} \mathrm{O}$, and (c) $\mathrm{C}^{18} \mathrm{O}$. Since we have $\mathrm{N}_{2}$ free impurity, the asterisk indicates the PdNNPd $\left(492 \mathrm{~cm}^{-1}\right)$ and PdNN $\left(367 \mathrm{~cm}^{-1}\right)$ species (see reference 47$)$.

The same experiments were carried out in neon, in a domain of smaller concentration to compensate for easier atomic and molecular diffusion. Typically, the $\mathrm{CO} / \mathrm{Ne}$ molar ratio was varied over the $200-400 \mathrm{ppm}$ range. Most of the features observed in argon are easily identified, with shifts of a few wavenumbers, and different site splitting (not reported in Table 1). However, one significant difference is the absence of signals labelled eo close to 2015 and $484 \mathrm{~cm}^{-1}$. This species can be observed and stabilized only in an argon matrix. The situation with $\mathrm{Pd}_{2}-\mathrm{N}_{2}$ is different since the eo species can be observed in neon, but with a more weak signal in comparison with the argon matrix. ${ }^{47}$ It seems that the rigidity of the argon matrix or stronger interaction with more polarizable argon atoms help to the stabilization of the end-on species. The higher stabilization by the argon cage was also observed on the triplet state of the CuNO complex [48], in comparison with the neon cage.

Concentration and annealing effects confirm the stoichiometry of the species responsible for all the bands observed in the various spectral domains. Note that the bands assigned to the 2:2, 3:1 and 4:1 species, are stronger in neon, in comparison with argon (see the bottom part of Fig. 1), since the atomic and molecular diffusion is easier. These bands appear upon Pd concentration increase and progressive annealing in the range 8$12 \mathrm{~K}$ leads to comparable observation. Also, it was possible to observe new band in the far-infrared for the $4: 1$ species (Table 1). 


\section{TABLE 1}

Vibrational frequencies $\left(\mathrm{cm}^{-1}\right)$ of the IR absorption bands observed for $\mathrm{Pd}_{\mathrm{m}}-(\mathrm{CO})_{\mathrm{n}}$ complexes trapped in Ar and Ne matrices

\begin{tabular}{|c|c|c|c|c|}
\hline assignment & $\mathbf{A r}$ & $\mathrm{Ne}$ & Stoichiometry & structure \\
\hline $2 v_{\mathrm{CO}}$ & 4103.4 & 4142.3 & $2: 2$ & \\
\hline $2 v_{\mathrm{CO}}$ & 4004.1 & - & $2: 1$ & eo \\
\hline $2 v_{\mathrm{CO}}$ & - & 3781.2 & $2: 2$ & \\
\hline $2 v_{\mathrm{CO}}$ & 3688.1 & 3732.4 & $2: 1$ & br \\
\hline $2 v_{\mathrm{CO}}$ & 3433.8 & 3476.5 & $3: 1$ & \\
\hline$v_{\mathrm{CO}}+v_{\mathrm{PdC}}$ & 2498.4 & - & $2: 1$ & eo \\
\hline$v_{\mathrm{CO}}$ & 2064.5 & 2084.0 & $2: 2$ & \\
\hline$v_{\mathrm{CO}}$ & 2044.2 & 2056.7 & $1: 1$ & \\
\hline$v_{\mathrm{CO}}$ & 2014.5 & - & $2: 1$ & eo \\
\hline$v_{\mathrm{CO}}$ & 1880.2 & 1903.0 & $2: 2$ & \\
\hline$v_{\mathrm{CO}}$ & 1856.5 & 1879.0 & $2: 1$ & br \\
\hline$v_{\mathrm{CO}}$ & 1729.4 & 1750.8 & $3: 1$ & \\
\hline$v_{\mathrm{CO}}$ & 1680.5 & 1707.7 & $4: 1$ & \\
\hline$\delta_{\mathrm{OCPd}}$ & 587.7 & 568.9 & $2: 1$ & br \\
\hline$\delta_{\mathrm{OCPd}}$ & - & 515.4 & $4: 1$ & \\
\hline$\gamma_{\mathrm{PdCO}}$ & 535.7 & 537.5 & $2: 2$ & \\
\hline$\delta_{\mathrm{OCPd}}$ & 499.7 & 482.6 & $3: 1$ & \\
\hline$v_{\mathrm{PdC}}$ & $483.7^{\mathrm{a}}$ & - & $2: 1$ & eo \\
\hline$v_{\mathrm{PdC}}$ & $472.1^{\mathrm{a}}$ & $470.8^{\mathrm{a}}$ & $1: 1$ & \\
\hline$\gamma_{\mathrm{PdCO}}$ & 386.5 & 367.8 & $2: 1$ & br \\
\hline
\end{tabular}

${ }^{\mathrm{a}} \mathrm{Pd}$ isotopic structure. Frequency for ${ }^{106} \mathrm{Pd}$ reported

\subsection{Irradiation effects}

Only those giving rise to the most significant effects will be described below. The results will be described only in argon since we don't observe the eo species in solid neon. The main result of the irradiation is 
the conversion between the eo and br structures of $\mathrm{Pd}_{2}-\mathrm{CO}$, and a little growth of the $\mathrm{Pd}_{3}-\mathrm{CO}$ band at $1729 \mathrm{~cm}^{-1}$, and the decrease of the weak $\mathrm{Pd}_{4}-\mathrm{CO}$ band at $1693.5 \mathrm{~cm}^{-1}$. Most selective conversion in Ar occurs at 365, 405, 436, 546, and between 600 and $700 \mathrm{~nm}$, but the efficient is not necessary the same for each wavelength. For the most efficient wavelengths at 405 and $546 \mathrm{~nm}$, we also observe the same effects on the weaker absorptions already correlated to eo and br species in the far- (Fig. 2) and near-infrared regions.

Irradiation at $\lambda=405$ and $546 \mathrm{~nm}$ : the effects of these two wavelengths are very similar. A strong intensity change are observed for eo and br bands, those on eo decreasing by $90 \%$ and these of br increasing by factors 1.5 after $15 \mathrm{~min}$ irradiation (Fig. 3). We observe also the growth of the band at $1729 \mathrm{~cm}^{-1}$, and the disappearance of the weak one at $1693.5 \mathrm{~cm}^{-1}$. The relative intensity variations versus time are displayed in Fig. S1. Defining the conversion advancement as $a_{t}=\left(I_{t}-I_{0}\right) /\left(I_{\infty}-I_{0}\right)$, where I means the intensity of one CO stretching band and the indices $0, \mathrm{t}$, and $\infty$ refer to the initial, intermediate and final times, we deduce that $\mathrm{a}_{\mathrm{t}}$ has the relatively the same value for eo and br whatever $t$. The characteristic time of conversion $t_{1 / 2}($ the time required for converting the half of the quantity converted at infinite time) is $45 \pm 5$ and $65 \pm 5 \mathrm{sec}$, for $\lambda=405$ and 546 $\mathrm{nm}$, respectively, whatever the isomer considered. Concerning the other species, one should mention that the 1:1 complex is not sensitive to this irradiation while the band at $1729 \mathrm{~cm}^{-1}$ has a characteristic time of only $7 \mathrm{sec}$. 


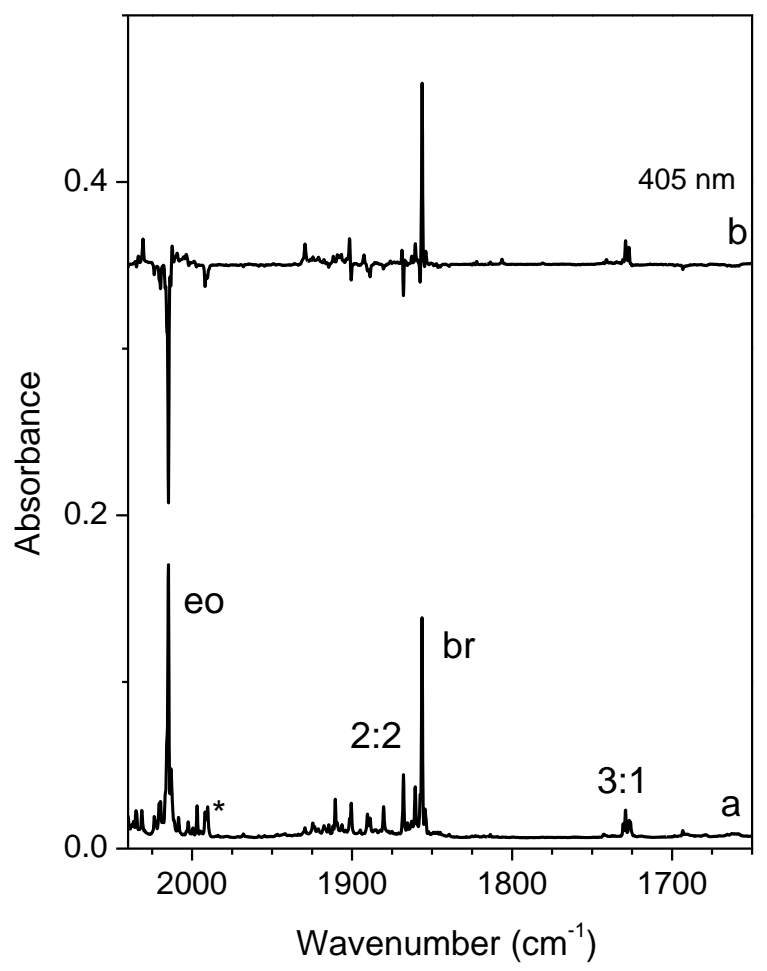

Fig. 3. Irradiation effects observed for samples with approximately the same $\mathrm{Pd} / \mathrm{CO} / \mathrm{Ar}$ molar ratios (3/1/1000). (a) Spectrum recorded just after deposition, (b) difference spectrum (after-before) 15 min irradiation at $\lambda_{\text {irr }}=405$ nm.

\section{Theoretical part}

We have considered different kinds of geometry (linear end-on, bent end-on, bridged and hollow positions) for both the singlet and triplet states. Cartesian coordinates of all the minima have been reported in the supplementary information.

In fig. 4 are gathered the most relevant structural and energetic data for the lowest lying structures found for four studied complexes $\left(\mathrm{Pd}_{2}-\mathrm{CO}, \mathrm{Pd}_{2}-(\mathrm{CO})_{2}, \mathrm{Pd}_{3}-\mathrm{CO}\right.$, and $\left.\mathrm{Pd}_{4}-\mathrm{CO}\right)$. The binding energy $\left(\mathrm{D}_{\mathrm{e}}\right)$ has been calculated with respect to the ground state of $\mathrm{Pd}_{2,3,4}$ and $\mathrm{CO}$ fragments for the $\mathrm{Pd}_{2}-\mathrm{CO}, \mathrm{Pd}_{3}-\mathrm{CO}$, and $\mathrm{Pd}_{4}-\mathrm{CO}$, while we used the $\mathrm{Pd}_{2}-\mathrm{CO}$ (singlet bridged structure) and $\mathrm{CO}$ fragments in the case of the planar $\mathrm{Pd}-(\mathrm{CO})_{2}$ compound. 


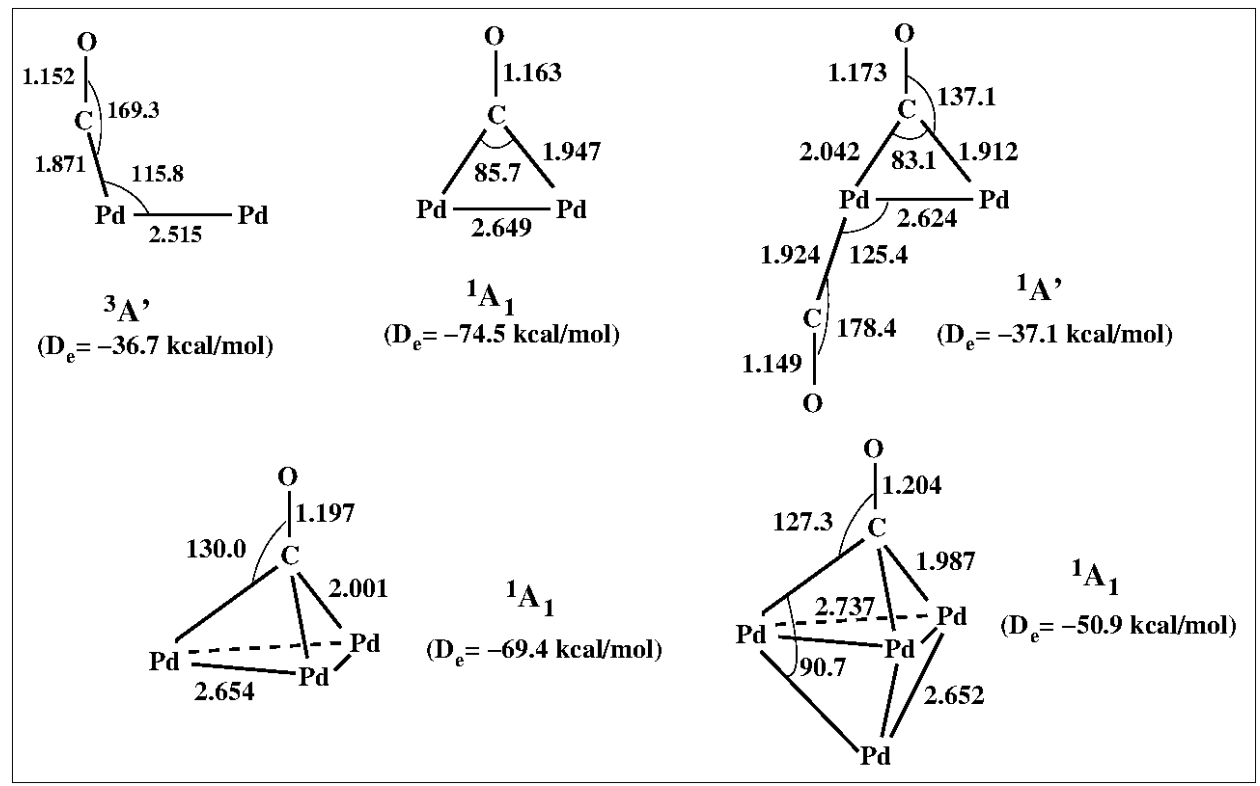

Fig. 4. Ground electronic state of different studied complexes. Distances are in angstrom and angles in degrees.

\subsection{Structural and energetic analysis}

In order to complete the structural study of $\mathrm{Pd}_{2}-\mathrm{CO}$, we investigated the potential energy profile of isomerization process at both singlet and triplet states joining the $\mathrm{C}_{2 \mathrm{v}}$ structure to the $\mathrm{C}_{\propto \mathrm{v}}$ structure through the $\mathrm{C}_{\mathrm{s}}$ structure (see Fig. 5). The energy, depicted on the vertical axis, represents the relative energy of each optimized point along the reaction path with respect to the ground state of subunits: $\operatorname{Pd}_{2}\left({ }^{3} \Sigma_{\mathrm{u}}^{+}\right)+\mathrm{CO}\left(\mathrm{X}{ }^{1} \Sigma^{+}\right)$. At each point of the potential energy curves, for a given value of the reaction coordinate (represented by angle $\theta$ in Fig. 5), all other geometrical parameters have been optimized within the Cs symmetry framework. 


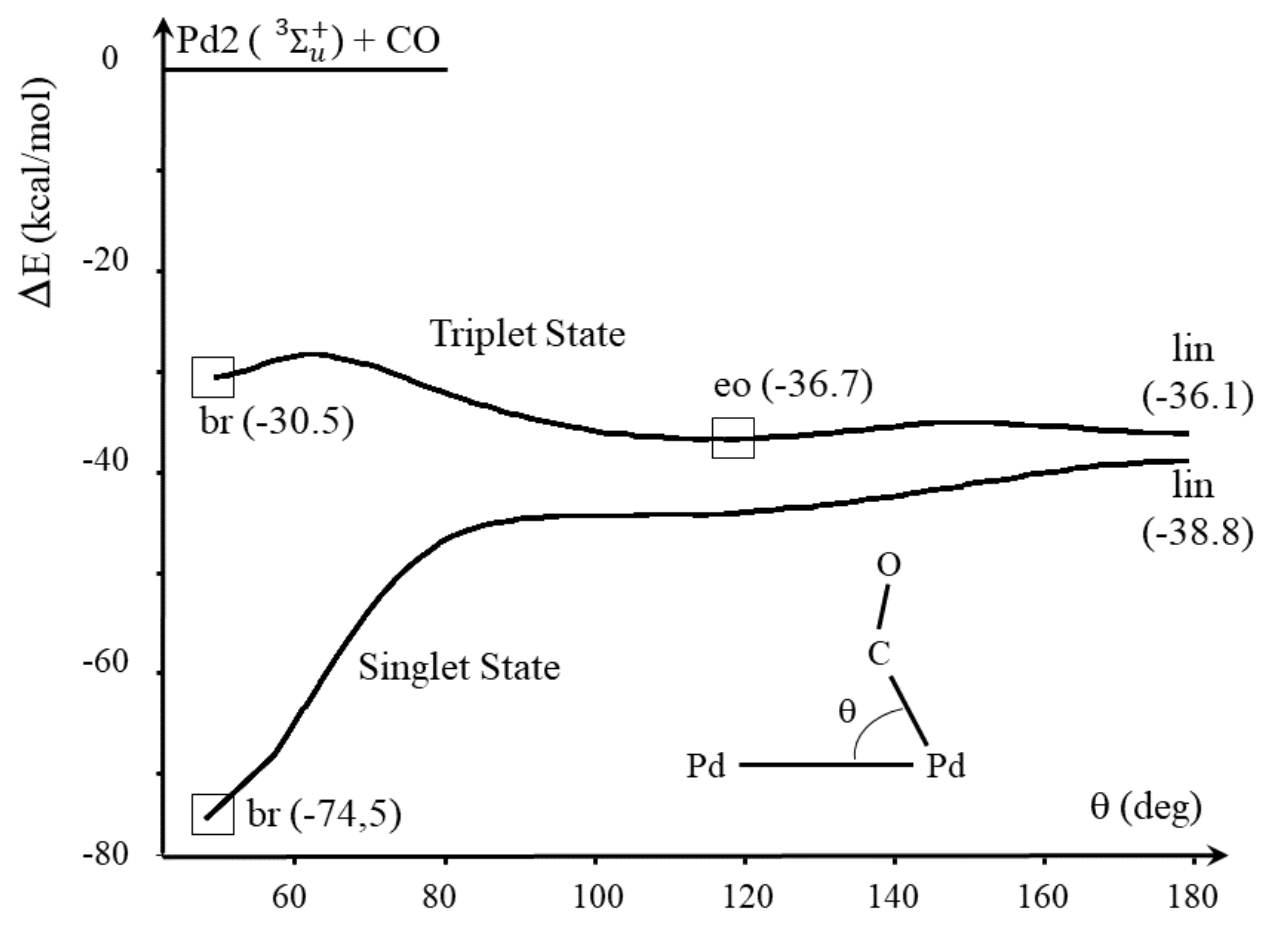

Fig. 5. Potential energy curves of $\mathrm{Pd}_{2} \mathrm{CO}$ at both singlet and triplet states along the reaction coordinate $\theta$.

We note that all of the triplet stationary points were calculated to be less stable than the singlet ones. Three local minima in the triplet state are connected via two transition states. The most stable triplet corresponds to the end-on structure with a binding energy around $-37 \mathrm{kcal} / \mathrm{mol}$. Transformation of two other local minima (bridged and linear structures) into the end-on structure in the triplet surface requests a small activation energy (about $2 \mathrm{kcal} / \mathrm{mol}$ ), nearly negligible with respect to their binding energies.

By contrast, linear structure (lin in Fig. 5) on the singlet state corresponds to a transition state (one imaginary frequency) which spontaneously undergoes to the bridged structure (br). Consequently, the singlet bridged (global minimum) and the triplet end-on (local minimum) are two candidates to be experimentally observed. It is interesting to note that our calculated binding energy for the singlet bridged structure (-74.5 
$\mathrm{kcal} / \mathrm{mol}$ ) is in excellent agreement with that obtained previously at an extended ab initio level of theory (MRSDCI-Q), $-75.5 \mathrm{kcal} / \mathrm{mol}[22]$.

It is furthermore worth noting to underline two noticeable differences between $\mathrm{Pd}_{2}-\mathrm{CO}$ and $\mathrm{Pd}_{2}-\mathrm{N}_{2}$ [47].

- Two selected minima of $\mathrm{Pd}_{2}-\mathrm{CO}$ (singlet bridged and triplet end-on) belong to two different multiplicities, in the contrast to the case of $\mathrm{Pd}_{2}-\mathrm{N}_{2}$ for which both structures were found in the singlet surface.

- Unlike to the case of $\mathrm{Pd}_{2}-\mathrm{N}_{2}$, two potential energy surfaces, namely singlet and triplet ones do not cross for the $\mathrm{Pd}_{2}-\mathrm{CO}$ complex. The TPSS calculated energy gap between singlet and triplet linear structures is very close to that obtained with MRSDCI-Q ${ }^{22}(2.7 v s .3 .7 \mathrm{kcal} / \mathrm{mol})$.

The most stable structures found for $\mathrm{Pd}_{3}-\mathrm{CO}, \mathrm{Pd}_{4}-\mathrm{CO}$ and $\mathrm{Pd}_{2}-(\mathrm{CO})_{2}$ are reported in Fig. 4. For $\mathrm{Pd}_{3}-\mathrm{CO}$ and $\mathrm{Pd}_{4}-\mathrm{CO}$, the hollow site attachment has the strongest $\mathrm{CO}$ adsorption energy in the singlet state, in agreement with the literature [19,28-33]. Interestingly, two $\mathrm{CO}$ molecules are not equivalent in the $\mathrm{Pd}_{2}-(\mathrm{CO})_{2}$ complex: one $\mathrm{CO}$ in bridged and other $\mathrm{CO}$ in end-on position. In agreement with the literature [26], the singlet state is the ground state of this complex. Note that for $\mathrm{Au}_{2}(\mathrm{CO})_{2}$, and $\mathrm{Ag}_{2}(\mathrm{CO})_{2}$, the calculations and the experimental results give a $\mathrm{D}_{\infty \mathrm{h}}$ and $\mathrm{C}_{2 \mathrm{~h}}$ structure, respectively $[4,10]$.

\subsection{Nature of chemical bonding in the $\mathrm{Pd}_{2}-\mathrm{CO}, \mathrm{Pd}_{3}-\mathrm{CO}, \mathrm{Pd}_{4}-\mathrm{CO}$ and $\mathrm{Pd}_{2}-(\mathrm{CO})_{2}$}

Within Bader's quantum theory of atoms in molecules (QTAIM), the bond path is a line of locally maximum electron density linking the nuclei of bonded atoms. Such a line is characterized by the existence of a $(3,-1)$ critical point which is referred to as a bond critical point $(\mathrm{BCP})$. Thus the bond path cover a complete spectrum of bonded-atoms in a chemical compound (molecule, organometallic compounds, non-covalent interactions, crystals, etc). The Laplacian of the electron density $\left(\nabla^{2} \rho\left(r_{c}\right)\right)$ enables one to determine the regions 
where electron density is locally concentrated $\left(\nabla^{2} \rho\left(r_{c}\right)<0\right)$ or locally depleted $\left(\nabla^{2} \rho\left(r_{c}\right)>0\right)$. Furthermore, the outer or valence shell of charge concentration (VSCC) could be evidenced by the topology of the Laplacian of the electron density [49]. In addition to the local properties defined at BCP $\left(\rho\left(r_{c}\right)\right.$ electron density, $\nabla^{2} \rho\left(r_{c}\right)$ Laplacian of the electron density, and $H\left(r_{c}\right)$ energy density), an integrated property such as the electron delocalization between two bended atoms $\left(\delta\left(r_{c}\right)\right.$ delocalization index) is often used to indicate more precisely the covalent character of the chemical bonding [49-51].

According to the QTAIM, the positive values of the Laplacian at the bond critical point are associated with closed-shell interactions (ionic bonds, hydrogen bonds, and van der Waals interactions), whereas, $\nabla^{2} \rho<0$, indicates shared interactions (covalent bonds). As has been proposed by Cremer and Kraka [52], the sign and magnitude of the total electronic energy density at the $\mathrm{BCP}, \mathrm{H}(\mathrm{r})$, could be used as another criterion to evaluate the importance of sharing of electrons (when $\mathrm{H}(\mathrm{r})<0$ ).

Electron delocalization counts the number of electrons shared between any two atomic basins in a chemical compound. As clearly underlined in Reference 50, electron delocalization can be related to bond order if and only if the atoms share a bond path. In Table 2 are gathered the topological descriptors of bonding in the compounds studied in this work. One can easily note existence of a bond path for $\mathrm{C}-\mathrm{O}, \mathrm{Pd}-\mathrm{C}$, and $\mathrm{Pd}-\mathrm{Pd}$ pairs of atoms. The Laplacian of the electron density is always positive indicating a closed-shell interaction between these bonded atoms. 


\section{TABLE 2}

Some local and global topological properties on the bonded atoms in the studied compounds. All parameters are given in atomic units.

\begin{tabular}{|c|c|c|c|}
\hline Compound & $B C P\left(r_{c}\right)$ & $\rho\left(r_{c}\right), \nabla^{2} \rho\left(r_{c}\right), H\left(r_{c}\right)$ & $\delta\left(r_{c}\right)$ \\
\hline$C O:{ }^{1} \Sigma^{+}$ & $\mathrm{C}-\mathrm{O}$ & $0.494,0.46,-0.94$ & 1.81 \\
\hline$P d_{2}:{ }^{3} \Sigma_{u}^{+}$ & $\mathrm{Pd}-\mathrm{Pd}$ & $0.066,0.14,-0.02$ & 1.42 \\
\hline \multirow{2}{*}{$P d_{3}:{ }^{1} A_{1}\left(C_{2 v}\right)$} & Iso-side $\mathrm{Pd}-\mathrm{Pd}$ & $0.066,0.15,-0.02$ & 1.29 \\
\hline & Base $\mathrm{Pd}-\mathrm{Pd}$ & $0.061,0.14,-0.02$ & 1.15 \\
\hline$P d_{4}:{ }^{3} A_{1}(\mathrm{Td})$ & $\mathrm{Pd}-\mathrm{Pd}$ & $0.055,0.13,-0.01$ & 0.88 \\
\hline \multirow{2}{*}{$\begin{array}{c}P d_{2} C O:{ }^{1} A_{1}\left(C_{2 v}\right) \\
\text { Bridged side-on }\end{array}$} & $\mathrm{C}-\mathrm{O}$ & $0.442,0.19,-0.82$ & 1.48 \\
\hline & $\mathrm{Pd}-\mathrm{C}$ & $0.147,0.28,-0.07$ & 1.05 \\
\hline \multirow{3}{*}{$\begin{array}{c}P d_{2} C O:{ }^{3} \mathrm{~A}^{\prime}\left(C_{s}\right) \\
\text { Bent end-on }\end{array}$} & $\mathrm{C}-\mathrm{O}$ & $0.471,0.40,-0.89$ & 1.61 \\
\hline & $\mathrm{Pd}-\mathrm{C}$ & $0.159,0.47,-0.08$ & 1.39 \\
\hline & $\mathrm{Pd}-\mathrm{Pd}$ & $0.063,0.15,-0.02$ & 1.28 \\
\hline \multirow{5}{*}{$\begin{array}{l}\quad P d_{2}(C O)_{2}:{ }^{1} \mathrm{~A}^{\prime}\left(C_{s}\right) \\
\text { Bent end-on }(\eta-C O) \\
\text { Bridged side-on }\left(\mu_{2}-C O\right)\end{array}$} & $\mathrm{C}-\mathrm{O}(\eta-C O)$ & $0.477,0.41,-0.90$ & 1.64 \\
\hline & $\mathrm{C}-\mathrm{O}\left(\mu_{2}-C O\right)$ & $0440,0.24,-0.83$ & 1.52 \\
\hline & $\mathrm{Pd}-\mathrm{C}(\eta-C O)$ & $0.138,0.49,-0.06$ & 1.22 \\
\hline & \multirow{2}{*}{$\mathrm{Pd}-\mathrm{C}\left(\mu_{2}-C O\right)$} & $0.116,0.25,-0.04$ & 0.78 \\
\hline & & $0.150,0.28,-0.07$ & 1.13 \\
\hline \multirow{2}{*}{$\begin{array}{c}P d_{3} C O:{ }^{1} A_{1}\left(C_{3 v}\right) \\
\text { Hollow position }\end{array}$} & $\mathrm{C}-\mathrm{O}$ & $0.425,0.05,-0.78$ & 1.40 \\
\hline & $\mathrm{Pd}-\mathrm{C}$ & $0.125,0.21,-0.05$ & 0.80 \\
\hline \multirow{3}{*}{$\begin{array}{c}\mathrm{Pd}_{4} C O:{ }^{1} A_{1}\left(C_{3 v}\right) \\
\text { Hollow position }\end{array}$} & $\mathrm{C}-\mathrm{O}$ & $0.418,0.01,-0.76$ & 1.38 \\
\hline & $\mathrm{Pd}($ equat $)-\mathrm{C}$ & $0.130,0.20,-0.06$ & 0.82 \\
\hline & $\operatorname{Pd}($ axial $)-\operatorname{Pd}($ equat $)$ & $0.050,0.11,-0.01$ & 0.78 \\
\hline
\end{tabular}

The electron density at the $\mathrm{C}-\mathrm{O} \mathrm{BCP}$ ranges from $0.418 \mathrm{e} / \mathrm{a}_{0}{ }^{3}\left(2.82 \mathrm{e} / \AA^{3}\right)$ in the $\mathrm{Pd}_{4}-\mathrm{CO}\left({ }^{1} \mathrm{~A}_{1}\right)$ to 0.494 $\mathrm{e} / \mathrm{a}_{0}{ }^{3}\left(3.33 \mathrm{e} / \AA^{3}\right)$ in free $\mathrm{CO}\left(\mathrm{X}^{1} \Sigma^{+}\right)$. The negative value of the energy density at the $\mathrm{C}-\mathrm{O} \mathrm{BCP}(\approx-0.85)$ evidence the polar covalent character of the $\mathrm{C}-\mathrm{O}$ chemical bonding. The electron delocalization between two 
atomic basins varies between 1.38 e $\left(\mathrm{Pd}_{4}-\mathrm{CO}\right)$ and 1.81 e (free $\left.\mathrm{CO}\right)$. It is clear that the $\mathrm{C}-\mathrm{O}$ bond strength decreases with the formation of the palladium-carbonyl complexes. Furthermore, the variation of the electron density at the $\mathrm{C}-\mathrm{O}$ BCP well correlates with the variation of the $\mathrm{C}-\mathrm{O}$ bond length with a correlation coefficient close to one $\left(\mathrm{R}^{2} \approx 0.98\right.$ in Fig. 6-a).
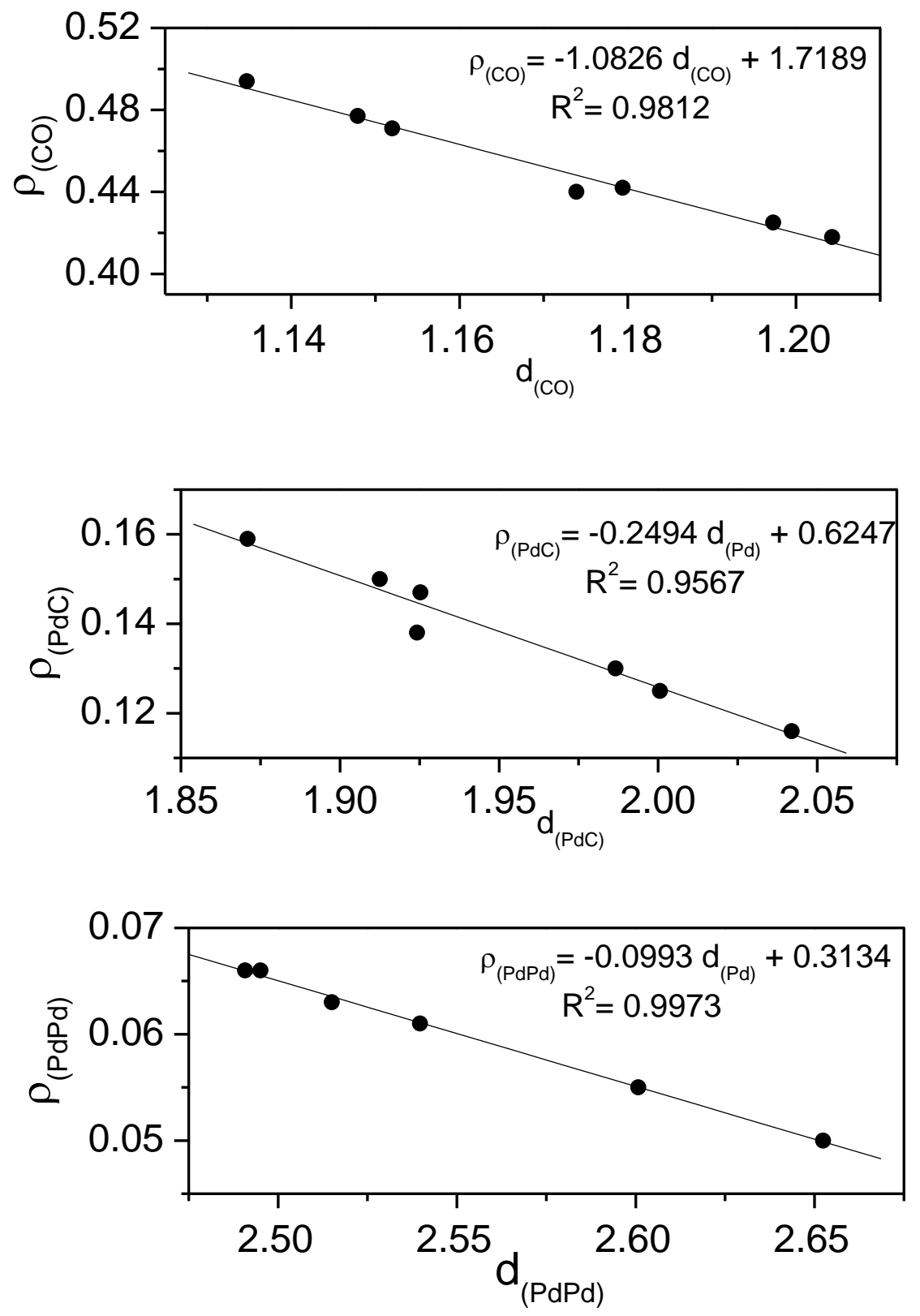

Fig. 6. Correlation between electron density at BCPs (in a.u.) and corresponding bond lengths (in $\AA$ ). 
The electron density at the BCP of $\mathrm{Pd}-\mathrm{C}$ is nearly four times smaller than that of $\mathrm{BCP} \mathrm{C}-\mathrm{O}$. It varies between $0.116 \mathrm{e} / \mathrm{a}_{0}{ }^{3}\left(0.783 \mathrm{e} / \AA^{3}\right)$ in the bridged side-on $\mathrm{Pd}_{2}-\mathrm{CO}\left({ }^{1} \mathrm{~A}_{1}\right)$ to $0.159 \mathrm{e} / \mathrm{a}_{0}{ }^{3}\left(1.073 \mathrm{e} / \AA^{3}\right)$ in the bent end-on $\mathrm{Pd}_{2}-\mathrm{CO}\left({ }^{3} \mathrm{~A}^{\prime}\right)$. The negative value of the energy density indicates the partially covalent character of the $\mathrm{Pd}-\mathrm{C}$ chemical bond. The number of shared electrons between two bonded atoms is around one electron. Here again, we note a good correlation between the electron density at $\mathrm{Pd}-\mathrm{C} \mathrm{BCP}$ and the $\mathrm{Pd}-\mathrm{C}$ bond length $\left(\mathrm{R}^{2} \approx\right.$ 0.96 in Fig. 6-b).

The smallest electron density was found at the Pd-Pd BCP varying from 0.050 e/a ${ }_{0}^{3}\left(0.337 \mathrm{e} / \AA^{3}\right)$ in the $\mathrm{Pd}_{4}$-CO $\left({ }^{1} \mathrm{~A}_{1}\right)$ complex to $0.066 \mathrm{e} / \mathrm{a}_{0}^{3}\left(0.445 \mathrm{e} / \AA^{3}\right)$ in the $\mathrm{Pd}_{2}$ dimer. It is interesting to underline that the $\mathrm{Pd}-\mathrm{Pd}$ BCP vanishes between two adjacent palladium atoms connected to the carbon atom of carbonyl, with the exception of the bent end-on $\mathrm{Pd}_{2}-\mathrm{CO}\left({ }^{3} \mathrm{~A}^{\prime}\right)$. A good correlation was also found between the electron density at $\mathrm{Pd}-\mathrm{Pd} \mathrm{BCP}$ and the $\mathrm{Pd}-\mathrm{Pd}$ bond length $\left(\mathrm{R}^{2} \approx 0.99\right.$ in Fig. 6-c).

As mentioned previously, it is possible to calculate an electron delocalization between two non-bonded atoms. For instance, it amounts around of 0.73 and 0.54 e for the non-bonded Pd atoms which are connected to the $\mathrm{C}$ atom, respectively in $\mathrm{Pd}_{3}-\mathrm{CO}$ and $\mathrm{Pd}_{4}-\mathrm{CO}$. Accordingly, there is indirect (through-bond) $\mathrm{Pd}-\mathrm{Pd}$ “contact", albeit without Pd - Pd bond path. In consistency with the three-center two-electron bonding concept in organometallic chemistry [53-55], we could speculate the presence of a $3 \mathrm{C}-2 \mathrm{e}$ interaction between three equatorial $\mathrm{Pd}$ atoms of $\mathrm{Pd}_{3}-\mathrm{CO}$ and $\mathrm{Pd}_{4}-\mathrm{CO}$ for which the total number of shared electrons is respectively $2.2 \mathrm{e}$ for $\mathrm{Pd}_{3}-\mathrm{CO}$ and 1.6 e for $\mathrm{Pd}_{4}-\mathrm{CO}$. We could also make suppositions on the existence of a two-center oneelectron interaction between two non-bonded $\mathrm{Pd}$ atoms in the $\mathrm{Pd}_{2}-\mathrm{CO}\left({ }^{1} \mathrm{~A}_{1}\right)$ and $\mathrm{Pd}_{2}-(\mathrm{CO})_{2}\left({ }^{1} \mathrm{~A}^{\prime}\right)$ complexes where the electron delocalization are around 0.95 and 0.75 e respectively. The latter consideration is in line with a previous theoretical study of the metal - metal bonding based on the covariance between the metal centers calculated within the electron localization function (ELF) framework [56-59]. In fact, the ELF covariance between two adjacent $\mathrm{Pd}$ core basins amounts -0.32 and -0.37 for $\mathrm{Pd}_{3}-\mathrm{CO}$ and $\mathrm{Pd}_{4}-\mathrm{CO}$, respectively. 
A careful study of the Laplacian contour maps for $(\mathrm{Pd})_{\mathrm{m}}-(\mathrm{CO})_{\mathrm{n}}(\mathrm{m}=2-4$ and $\mathrm{n}=0$ and 1$)$ reported in Fig. 7 enable us to underline three properties relative to the presence of $\mathrm{Pd}-\mathrm{C}$ bond paths in the $(\mathrm{Pd})_{\mathrm{m}}-(\mathrm{CO})_{\mathrm{n}}$ complex.

- Pronounced charge-concentrated part of the $\mathrm{C}$ basin is directed to the charge-depleted site on the outer valence shell of Pd atoms.

- BCPs between two adjacent Pd atoms (connected to bridging carbonyl) disappear upon formation of the palladium - carbonyl complex.

- Formation of $\mathrm{Pd}-\mathrm{C}$ BCPs is accompanied by a substantial polarization of the charge concentrated basin of $\mathrm{C}$ which could be easily identified by the changes in the magnitude of the atomic quadrupole moment. For free CO at TPSS/6-311+G(2df) level of theory we found $|\mathbf{Q}(\mathrm{C})|=0.22$ a.u. The values of $|\mathbf{Q}(\mathrm{C})|$ in $(\mathrm{Pd})_{\mathrm{m}}-\mathrm{CO}$ increases by factors of 12,8 and 4 for $\mathrm{n}=2,3$ and 4 , respectively.

A significant charge transfer occurs from metals to the carbonyl ligand upon the formation of the complex: 0.24, 0.32 and $0.34 e$ for $\mathrm{Pd}_{2}-\mathrm{CO}, \mathrm{Pd}_{2}-\mathrm{CO}$ and $\mathrm{Pd}_{4}-\mathrm{CO}$, respectively.

In summary, the bonding picture given by QTAIM could be paralleled with the Chatt-Dewar-Duncanson (DCD) model of $d \pi-p \pi^{*}$ backbonding in metal carbonyls [59]. 


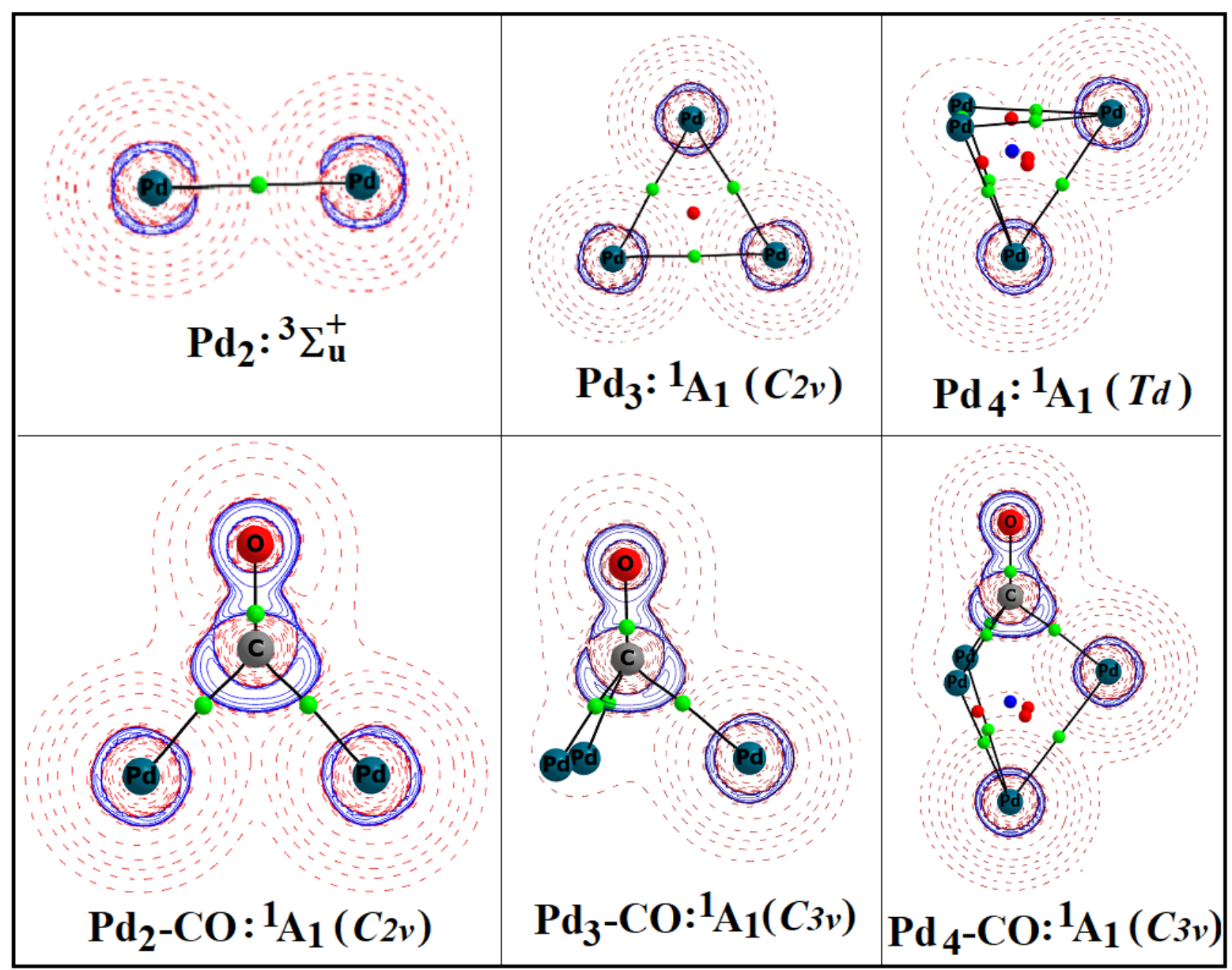

Fig. 7. Laplacian contour maps of the $(\mathrm{Pd})_{2,3,4}-\mathrm{CO}$ structures, at the singlet state. Solid lines (blue) stand for $\nabla^{2} \rho$ $<0$ and dashed ones (red) for $\nabla^{2} \rho>0$. The green circles represent BCPs, and the red and blue ones stand respectively for the RCP (ring critical point) and CCP (cage critical point).

\section{Vibrational analysis and discussion}

This section is devoted to compare the experimental vibrational frequencies to the theoretical ones. First, the positions of twelve absorption bands have been clearly established (Table 1). For 2:1 eo, two bands are very weak and located above the strong carbonyl stretching absorption, and are identified to be overtone and combination bands. For 2:1 br, 3:1 and 2:2, we observe clearly the $\mathrm{CO}$ overtone. For 2:1 eo, it is expected that 
the metal-CO stretching isotopic shift $(\Delta v)$ would be higher for the ${ }^{12} \mathrm{C}^{18} \mathrm{O}$ isotope in comparison with the ${ }^{13} \mathrm{C}^{16} \mathrm{O}$ one. This is observed for the band at $483.2 \mathrm{~cm}^{-1}$ and we have assigned it to the $v_{\mathrm{PdC}}$ stretching mode. Note that a Pd isotopic structure has been also observed for this band (Fig. 2). For a Pd-C-O bending mode, it is expected that $\Delta v\left(\mathrm{Pd}_{2}{ }^{13} \mathrm{C}^{16} \mathrm{O}\right)>\Delta v\left(\mathrm{Pd}_{2}{ }^{12} \mathrm{C}^{18} \mathrm{O}\right)$, and this is observed for the other far-infrared bands for the 2:1 br, $3: 1,4: 1$, and $2: 2$.

The theoretical vibrational frequencies have been calculated within the harmonic approximation for all compounds (see Table S2-SI). In Table 3 are gathered the experimentally observed frequencies, with the relative infrared intensities and the isotopic frequency-shifts, and the theoretical values for which it was possible to do a comparison with the experimental data. For all the molecules, we observe that the calculated values are in a good agreement with the experimental ones, and the experimental attributions to stretching or bending modes are well confirmed by the calculations. Compared to the free $\mathrm{CO}$ complex, the calculated red-shifts are 122, 291, 412, and $454 \mathrm{~cm}^{-1}$ for the $\mathrm{Pd}_{2}-\mathrm{CO}$ eo, $\mathrm{Pd}_{2}-\mathrm{CO}$ br, $\mathrm{Pd}_{3}-\mathrm{CO}$, and $\mathrm{Pd}_{4}-\mathrm{CO}$ complexes, respectively, which are furthermore in very good agreement with the experimental ones, 124, 282, 409, and $445 \mathrm{~cm}^{-1}$.

It is interesting to compare the $\mathrm{Pd}_{2}-(\mathrm{CO})_{2}$ complex with $\mathrm{Fe}_{2}(\mathrm{CO})_{9}$ because both contain terminal and bridging $\mathrm{CO}$. The observed red-shift of about $190 \mathrm{~cm}^{-1}$ between the terminal and bridging $\mathrm{CO}$ in the $\mathrm{Fe}_{2}(\mathrm{CO})_{9}$ complex [60], is very close to the red-shift in the case of $\mathrm{Pd}_{2}-(\mathrm{CO})_{2}$ species $\left(181 \mathrm{~cm}^{-1}\right)$. The presence of only one $\mathrm{CO}$ complex in the eo and br species is well supported by the presence of only two $\mathrm{C}-\mathrm{O}$ stretching bands in a sample containing mixtures of ${ }^{13} \mathrm{CO}$ and ${ }^{13} \mathrm{C}^{18} \mathrm{O}$. 


\section{TABLE 3}

Experimental frequencies (in solid argon) and theoretical harmonic vibrational data (in $\mathrm{cm}^{-1}$ ) of studied species, with the isotopic shifts. Relative intensities are in parentheses. ${ }^{b}$

\begin{tabular}{|c|c|c|c|c|c|c|c|}
\hline & \multirow{2}{*}{ Mode } & \multicolumn{3}{|c|}{ Experiment } & \multicolumn{3}{|c|}{ DFT } \\
\hline & & ${ }^{12} \mathrm{C}^{16} \mathrm{O}$ & ${ }^{13} \mathrm{C}^{16} \mathrm{O}$ & ${ }^{12} \mathrm{C}^{18} \mathrm{O}$ & ${ }^{12} \mathrm{C}^{16} \mathrm{O}$ & ${ }^{13} \mathrm{C}^{16} \mathrm{O}$ & ${ }^{12} \mathrm{C}^{18} \mathrm{O}$ \\
\hline \multirow{3}{*}{${ }^{1}\left[\mathrm{Pd}_{2}\left(\left(\eta^{2}-\mathrm{CO}\right)\right]\right.$} & $\delta_{\mathrm{OCPd}}$ & $386.5(1)$ & -12.6 & -3.6 & $369(1.3)$ & -12 & -5 \\
\hline & $\delta_{\mathrm{OCPd}}$ & $587.7(11)$ & -19.7 & -2.4 & $575(4.6)$ & -21 & -1 \\
\hline & $v_{\mathrm{CO}}$ & $1856.5(100)$ & -42.7 & -41.5 & $1850(100)$ & -41 & -40 \\
\hline \multirow[t]{2}{*}{${ }^{3}\left[\mathrm{Pd}_{2}\left(\eta^{1}-\mathrm{CO}\right)\right]$} & $v_{\mathrm{PdC}}$ & $483.9(1)$ & -6.0 & -13.7 & $453(0.8)$ & -7 & -12 \\
\hline & $v_{\mathrm{CO}}$ & $2014.9(100)$ & -46.9 & -44.0 & $2021(100)$ & -47 & -46 \\
\hline \multirow[t]{2}{*}{${ }^{1}\left[\mathrm{Pd}_{3}\left(\left(\eta^{3}-\mathrm{CO}\right)\right]\right.$} & $\delta_{\mathrm{OCPd}}$ & $499.7(12)$ & -16.9 & -1.8 & $490(4.4)$ & -17 & -1 \\
\hline & $v_{\mathrm{CO}}$ & $1729.4(100)$ & -39.4 & -39.5 & $1729(100)$ & -39 & -40 \\
\hline \multirow[t]{2}{*}{${ }^{1}\left[\mathrm{Pd}_{4}\left(\left(\eta^{3}-\mathrm{CO}\right)\right]\right.$} & $\delta_{\mathrm{OCPd}}$ & $515.4(5)$ & -16.8 & -1.8 & $517(3.0)$ & -18 & -1 \\
\hline & $v_{\mathrm{CO}}$ & $1707.7(100)$ & -38.8 & -39.5 & $1682(100)$ & -37 & -39 \\
\hline \multirow[t]{3}{*}{${ }^{1}\left[\mathrm{Pd}_{2}\left(\left(\eta^{2}-\mathrm{CO}\right)\left(\eta^{1}-\mathrm{CO}\right)\right]\right]$} & $\gamma_{\mathrm{PdCO}}{ }^{\mathrm{c}}$ & $535.7(13)$ & -15.8 & -4.7 & $556(4.4)$ & -18 & -3 \\
\hline & $v_{\mathrm{CO}}{ }^{\mathrm{c}}$ & $1880.2(91)$ & -43.0 & -43.4 & $1874(72)$ & -42 & -43 \\
\hline & $v_{\mathrm{CO}}{ }^{\mathrm{c}}$ & $2064.5(100)$ & -47.3 & -47.4 & $2054(100)$ & -48 & -47 \\
\hline
\end{tabular}

${ }^{\mathrm{a}}$ For $\mathrm{Pd}_{4}-\mathrm{CO}$, the experimental results are in solid neon since we observe the $\delta_{\mathrm{OCPd}}$ band only in neon.

${ }^{b}$ Relative IR intensities (with respect to the strongest fundamental of each specie: $\left.v_{\mathrm{CO}}\left(\mathrm{I}_{\mathrm{CO}}=100\right)\right)$.

${ }^{c}$ The $\gamma_{\mathrm{PdCO}}$ mode is the out of plane bending of the $\eta^{2}-\mathrm{CO}$, the first $v_{\mathrm{CO}}$ is for the $\eta^{2}-\mathrm{CO}$, and the second $v_{\mathrm{CO}}$ is for the $\eta^{1}-\mathrm{CO}$.

\section{Conclusion}

The study of the Pd $+\mathrm{CO}$ reaction was performed by coupling matrix isolation FTIR spectroscopy and DFT calculations. New infrared absorption data have been observed for $\mathrm{Pd}_{\mathrm{m}}-\mathrm{CO}(\mathrm{m}=2-4)$ and $\mathrm{Pd}_{2}-(\mathrm{CO})_{2}$ molecules. The more intense band, the CO stretching, appears in 2015-1700 $\mathrm{cm}^{-1}$ range and other absorptions 
are observed in the far and the near-infrared. In argon, the $\mathrm{Pd}_{2}-\mathrm{CO}$ side on isomer can be converted by photochemistry processes to $\mathrm{Pd}_{2}-\mathrm{CO}$ bridged isomer.

The experimental data obtained in argon and neon, with the help of isotopic effects, are fully supported by theoretical calculations density. The most relevant structural and energetic data for the lowest lying structures has been calculated for the four studied complexes.

Concerning the nature of chemical bonding between metal-metal and metal-ligand, it has been shown that the metal-metal bond disappears upon the formation of the complex with carbon monoxide. Metal-metal bonding should be considered as a through-bond owing the bridge-carbonyl ligand.

\section{Supporting Information}

Time development of the interconversion of the 2:1 species upon irradiation effects at three wavelengths (405, 546 and higher that $600 \mathrm{~nm}$ ) are gathered in Figure S1 for the C-O stretching region.

The cartesian coordinates of all the studied structures are reported in Table S1.

\section{Acknowledgements}

Many helpful discussions with J.P. Perchard are gratefully acknowledged. 


\section{References}

[1] G.A. Ozin, M. Moskovits, Cryochemistry, Wiley, New York, 1976.

[2] B. Tremblay, L. Manceron, G.L. Gutsev, L. Andrews, H. Partridge III, J. Chem. Phys. 117 (2002) 8479.

[3] B. Tremblay, G.L. Gutsev, L. Andrews, L. Manceron, J. Phys. Chem. A. 106 (2002) 10525.

[4] L. Jiang, Q. Xu, J. Phys. Chem. A. 109 (2005) 1026.

[5] L. Jiang, Q. Xu, J. Am. Chem. Soc. 127 (2005) 42.

[6] L. Jiang, Q. Xu, J. Chem. Phys. 122 (2005) 034505.

[7] Q. Xu, L. Jiang, N. Tsumori, Angew. Chem. Int. Ed. 44 (2005) 4338.

[8] Q. Xu, L. Jiang, R.Q. Zou, Chem. Eur. J. 12 (2006) 3226.

[9] L. Jiang, Q. Xu, J. Phys. Chem. A. 110 (2006) 5636.

[10] L. Jiang, Q. Xu, J. Phys. Chem. A. 110 (2006) 11488.

[11] X. Jin, L. Jiang, Q. Xu, M. Zhou, J. Phys. Chem. A. 110 (2006) 12585.

[12] L. Jiang, Q. Xu, J. Phys. Chem. A. 111 (2007) 2690.

[13] S. M. Souvi, N. Berkaïne, M.E. Alikhani, L. Manceron, Phys. Chem. Chem. Phys. 11 (2009) 9831.

[14] L. Jiang, Q. Xu, J. Chem. Phys. 128 (2008) 124317.

[15] L. Jiang, Q. Xu, Chem. Phys. 354 (2008) 32.

[16] T. Lear, R. Marshall, J.A. Lopez-Sanchez, S.D. Jackson, T.M. Klapotke, M. Baumer, G. Rupprechter, H.J.

Freund, D. Lennon, J. Chem. Phys. 123 (2005) 174706.

[17] B. Liang, M. Zhou, L. Andrews, J. Phys. Chem. A. 104 (2000) 3905.

[18] J. Andzelm, D.R. Salahub, Int. J. Quantum. Chem. 29 (1986) 1091.

[19] G. Pacchioni, J. Koutechý, J. Phys. Chem. 91 (1987) 2658.

[20] M.R.A. Blomberg, C.B. Lebrilla, P.E.M. Siegbahn, Chem. Phys. Lett. 150 (1988) 522.

[21] G. Pacchioni, P.S. Bagus, J. Chem. Phys. 93 (1990) 1209.

[22] D. Dai, S. Roszak, K. Balasubramanian, J. Chem. Phys. 104 (1996) 1471.

[23] A. Rochefort, R. Fournier, J. Phys. Chem. 100, (1996) 13506.

[24] T. Bredow, G. Pacchioni, Surf. Sci. 426 (1999) 106.

[25] V. Durà-Vilà, J.D. Gale, J. Phys. Chem. B 105 (2001) 6158.

[26] P. Nava, M. Sierka, R. Ahlrichs, Phys. Chem. Chem. Phys. 6 (2004) 5338.

[27] N.E. Schultz, G.F. Gherman, C.J. Cramer, D.G. Truhlar, J. Phys. Chem. B 110 (2006) 24030.

[28] A.M. Joshi, M.H. Tucker, W.N. Delgass, K.T. Thomson, J. Chem. Phys. 125 (2006) 194707. 
[29] S. Sicolo, G. Pacchioni, Surf. Sci. 602 (2008) 2801.

[30] B. Kalita, R.C. Deka, Eur. Phys. J. D. 53 (2009) 51.

[31] G. Zanti, D. Peeters, Eur. J. Inorg. Chem. (2009) 3904.

[32] Z. Zhao, Y. Ren, Y. Ren, J. Wang, W. Yin, J. Mol. Struct. (THEOCHEM) 955 (2010) 66.

[33] S.L. Peng, L.Y. Gan, R.U. Tian, Y.U. Zhao, Comp. Theo. Chem. 977 (2011) 62.

[34] M.A. Addicoat, M.A. Buntine, B. Yates, G.F. Metha, J. Comput. Chem 29 (2008) 1497.

[35] V. Bertin, E. Agacino, R. López-Rendon, E. Poulain, J. Mol. Struct. (THEOCHEM) 796 (2006) 243.

[36] K.M. Neyman, N. Rösch, G. Pacchioni, Appl. Catal. A: Gen. 191 (2000) 3.

[37] M.C. Valero, P. Raybaud, P. Sautet, J. Catal. 247 (2007) 339.

[38] B. Kalita, R.C. Deka, J. Am. Chem. Soc. 131 (2009) 13252.

[39] B. Kalita, R.C. Deka, J. Comput. Chem. 31 (2010) 2476.

[40] B.D. Adams, R.M. Asmussen, A.M. Chen, R.C. Mawhinney, Can. J. Chem. 89 (2011) 1445.

[41] D. Danset, L. Manceron, J. Phys. Chem. A 107, (2003) 11324.

[42] M.J. Frisch, G.W. Trucks, H.B. Schlegel et al., GAUSSIAN 03, Revision D.02, Gaussian, Inc., Wallingford CT, 2004.

[43] R.F.W. Bader, Atoms in Molecules: A Quantum Theory, Clarendon, Oxford, U.K. 1990.

[44] AIMAll (Version 17.11.14), Todd A. Keith, TK Gristmill Software, Overland Park KS, USA, 2017 (aim.tkgristmill.com).

[45] J.H. Darling, J.S. Ogden, J. Chem. Soc. Dalton Trans. (1973) 1079.

[46] B. Tremblay and L. Manceron,Chem. Phys. 250 (1999) 187.

[47] S.M. Souvi, B. Tremblay, J.P. Perchard, M.E. Alikhani, J. Chem. Phys. 130 (2009) 074304.

[48] L. Krim, X. Wang, L. Manceron, L. Andrews, J. Phys. Chem. A, 109 (2005) 10264.

[49] R. F. W. Bader, C. F. Matta, Found Chem 15 (2013) 253.

[50] C. Matta, J. Comput. Chem. 35 (2010) 1165.

[51] C. Matta, Comput. Theor. Chem. 1124 (2018) 1.

[52] D. Cremer, E. Kraka, Angew. Chem., Int. Ed. Engl. 23 (1984) 627.

[53] P. L. A. Popelier, in Applications of Topological Methods in Molecular Chemistry,Vol 2, edited by R.

Chauvin, C. Lepetit, E. Alikhani, B. Silvi, Publisher Springer, Switzerland, 2016, chap: On Quantum Chemical Topology.

[54] L.J. Farrugia, P. Macchi, in Structure and Bonding, 146, 127 Springer-Verlag Berlin and Heidelberg, 2012. [55] J.C. Green, M.L.H. Green, G. Parkin, Chem. Commun. 48 (2012) 11481. 
[56] M. E Alikhani, M.C. Michelini, N. Russo, B. Silvi, J. Phys. Chem. A 112 (2008) 2966.

[57] R. Llusar, A. Beltrán, J. Andrés, F. Fuster, B. Silvi, J. Phys. Chem. A 105 (2001) 9460.

[58] C. Lepetit, P. Fau, K. Fajerwerg, M.L. Kahn, B. Silvi, Coord. Chem. Rev. 345 (2007) 150.

[59] G. Frenking, in G. C. Leigh, N. Winterton (Eds.), Modern Coordination Chemistry: The Legacy of Joseph Chatt, The Royal Society of Chemistry, London, 2002, p. 111.

[60] S.C. Fletcher, M. Poliakoff, J. Turner, J. Inorg. Chem. 25 (1986) 3597. 